\title{
PENGARUH MODEL PEMBELAJARAN INTEGRATIF TERHADAP KOMUNIKASI MATEMATIS SISWA KELAS IX SMP NEGERI 8 KENDARI
}

\author{
Randita Cahyani Hamlin ${ }^{1)}$, Moh. Salam ${ }^{2)}$, Kodirun $^{3)}$ \\ ${ }^{1)}$ Alumni Jurusan Pendidikan Matematika, ${ }^{2,3)}$ Dosen Jurusan Pendidikan Matematika \\ FKIP Universitas Halu Oleo, Email: ditahamlin@gmail.com
}

\begin{abstract}
Abstrak
Penelitian ini bertujuan untuk mengetahui: 1) deskripsi kemampuan komunikasi matematis siswa kelas IX SMP Negeri 8 Kendari yang diajar dengan model pembelajaran integratif, 2) deskripsi kemampuan komunikasi matematis siswa kelas IX SMP Negeri 8 Kendari yang diajar dengan model pembelajran konvensional, dan 3) perbedaan pengaruh model pembelajaran integratif dan model pembelajran konvensional pada kemampuan komunikasi matematis siswa kelas IX SMP Negeri 8 Kendari. Populasi dalam penelitian ini adalah seluruh siswa kelas IX SMP Negeri 8 Kendari. Teknik pengambilan sampel dalam penelitian ini menggun akan teknik Purposive Sampling. Teknik pengumpulan data dilakukan dengan pemberian tes kemampuan komunikasi matematis. Teknik analisis data menggunakan statistik deskriptif dan statistik inferensial. Hasil penelitian ini menunjukkan bahwa: kemampuan komunikasi matematis siswa yang diajar dengan model pembelajaran integratif diperoleh nilai terendah 35 , nilai tertinggi 90 , mean 66,67 ., median 65,00 , modus 65, standar deviasi 13,814., dan varians 190,833. Kemampuan komunikasi matematis siswa yang diajar dengan model pembelajaran konvensional diperoleh nilai terendah 30, nilai tertinggi 80 , mean 54,74., median 60,00, modus 70, standar deviasi 17,117 dan varians 292,983.
\end{abstract}

Kata Kunci: Model Pembelajaran Integratif, Kemampuan Komunikasi Matematis

\section{THE EFFECT OF INTEGRATIVE LEARNING MODELS ON MATHEMATICAL COMMUNICATION SKILLS OF CLASS IX STUDENTS OF STATE 8 KENDARI SMP}

\begin{abstract}
This study aims to find out: 1) description of mathematical communication skills of class IX students of SMP Negeri 8 Kendari which are taught with integrative learning models, 2) description of mathematical communication skills of IX grade students of SMP Negeri 8 Kendari which are taught using conventional learning models, and 3) differences the influence of integrative learning models and conventional learning models on mathematical communication skills of class IX students of SMP Negeri 8 Kendari. The population in this study were all IX grade students of SMP Negeri 8 Kendari. The sampling technique in this study used purposive sampling technique. Data collection techniques were carried out by giving a test of mathematical communication skills. Data analysis techniques use descriptive statistics and inferential statistics. The results of this study indicate that: mathematical communication skills of students taught with integrative learning models obtained the lowest value of 35 , the highest score of 90, mean of 66.67. Median 65.00, mode 65, standard deviation 13,814. And variance 190,833. Mathematical communication skills of students taught with conventional learning models obtained the lowest value of 30, the highest score of 80, mean 54.74., Median 60.00, mode 70 , standard deviation of 17.117 and variance 292,983 .
\end{abstract}

Keywords: Integrative, Mathematical Communication Ability 


\section{Pendahuluan}

Undang-Undang Republik Indonesia Nomor 20 tahun 2003 tentang sistem pendidikan nasional yaitu mengembangkan kemampuan dan membentuk watak serta peradaban bangsa yang bermartabat dalam rangka mencerdaskan kehidupan bangsa, bertujuan untuk mengembangkan potensi peserta didik agar menjadi manusia yang beriman dan bertakwa kepada Tuhan Yang Maha Esa, berakhlak mulia, sehat, berilmu, cakap, kreatif, mandiri dan menjadi warga negara yang demokratis serta bertanggung jawab. Oleh karena itu, cara yang efektif untuk meningkatkan sumber daya manusia Indonesia antara lain melalui peningkatan kualitas pendidikan (Sumantri, 2015: 101).

Pendidikan merupakan kebutuhan yang sangat penting dalam kehidupan manusia, dimana prosesnya dinamis dan berkelanjutan. Pendidikan dilakukan secara terencana dalam mewujudkan proses pembelajaran agar siswa aktif mengembangkan potensi diri dan keterampilan yang dimiliki sebagai bekal kehidupan bermasyarakat. Dengan demikian, pendidikan dapat membantu mengarahkan siswa menjalani kehidupan sebaagai makhluk yang beragama dan makhluk sosial dengan baik. Hal ini sesuai dengan tujuan pendidikan nasional yang tercantum dalam Undang-Undang Republik Indonesia Nomor 20 tahun 2003 tentang Sistem Pendidikan Nasional Bab 1 ayat 2: "Tujuan Pendidikan Nasional adalah mengembangkan kemampuan dan membentuk watak serta peradaban bangsa yang bermartabat dalam rangka mencerdaskan kehidupan bangsa dan untuk mengembangkan potensi peserta didik agar menjadi manusia yang beriman dan bertaqwa kepada Tuhan Yang Maha Esa, berakhlak mulia, sehat, berilmu, cakap, kreatif, mandiri, dan menjadi warga negara yang demokratis serta bertanggung jawab".

Pendidikan adalah usaha sadar dan terencana untuk mewujudkan suasana belajar dan proses pembelajaran agar peserta didik secara aktif mengembangkan potensi dirinya untuk memiliki kekuatan spiritual keagamaan, pengendalian diri, kepribadian, kecerdasan, akhlak mulia, serta keterampilan yang diperlukan dirinya, masyarakat, bangsa dan negara. Dalam rangka untuk mengembangkan potensi tersebut, salah satu usaha yang dilakukan melalui pembelajaran matematika. Salah satu yang dapat dilakukan untuk meningkatkan kualitas diri manusia yaitu melalui pendidikan. Pendidikan adalah humanisasi, yaitu upaya memanusiakan atau upaya membantu manusia agar mampu mewujudkan diri sesuai dengan martabat kemanusiaannya (Wahyudin, 2011: 1.29).

Pembelajaran matematika sebagai salah satu mata pelajaran yang wajib diikuti oleh siswa di sekolah dari jenjang pendidikan dasar. Hal ini dimaksudkan untuk membekali mereka dengan kemampuan berpikir logis, analitis, sistematis, kritis, kreatif, serta kemampuan bekerja sama (Daryanto. 2013: 411). Sesuai dengan National Council of Teacher of Mathematics (NCTM), tuuan umum siswa belajar matematika pada poin keempat yaitu: belajar berkomunikasi secara matematis, belajar tentang simbol, lambing dan kaedah matematis (Bernard, 2015: 198).

Beberapa alasan pentingnya kemampuan komunikasi matematis siswa dikembangkan dalam pembelajaran matematika. Pertama, kemampuan komunikasi diperlukan untuk mempelajari bahasa dan simbol-simbol matematika serta mengeksplorasikan ide-ide matematis. Kedua, komunikasi juga bermanfaat untuk melatih siswa dalam mengemukakan gagasan secara jujur berdasarkan fakta, rasional, serta meyakinkan orang lain dalam rangka memperoleh pemahaman bersama.

Rendahnya kemampuan komunikasi matematis siswa kelas IX SMPN 8 Kendari disebabkan oleh beberapa faktor seperti faktor siswa itu sendiri, guru, metode pembelajaran, maupun lingkungan belajar yang saling berhubungan satu sama lain. Faktor dari siswa itu sendiri adalah kurangnya pemahaman konsep siswa terhadap materi yang diajarkan, kurangnya aktivitas siswa dalam berdiskusi atau menulis matematis. Faktor dari guru adalah memfokuskan pembelajaran matematika pada upaya penyampaian materi matematika sebanyak mungkin kepada siswa sehingga menyebabkan siswa jenuh dalam menjalani proses belajar mengajar. Jadi kurangnya kemampuan komunikasi matematis siswa akan mempengaruhi tinggi rendahnya hasil belajar yang diperoleh.

Pada setiap proses pembelajaran selalu terjadi komunikasi, proses komunikasi terjadi 
antara guru yang memiliki sejumlah pesan yang ingin disampaikan kepada siswa sebagai penerima pesan. Komunikasi yang dimaksud adalah kemampuan siswa dalam menyampaikan atau menerima gagasan, sehingga terjadi proses belajar. Komunikasi dalam pembelajaran matematika memiliki peran yang cukup penting, pada dasarnya matematika merupakan suatu bahasa simbolik dan belajaran matematika merupakan aktivitas sosial. Pada pembelajaran matematika yang berpusat pada siswa, pemberi pesan tidak terbatas pada guru saja melainkan dapat dilakukan oleh siswa maupun orang lain. Pesan yang dimaksud adalah konsep-konsep matematika, dan cara menyampaikan pesan dapat dilakukan baik melalui lisan maupun tulisan.

Sumantri (2015: 371) komunikasi dalam pembelajaran merupakan proses transformasi pesan berupa ilmu pengetahuan dan teknologi dari pendidik kepada peserta didik, dimana peserta didik mampu memahami maksud pesan sesuai dengan tujuan yang telah ditentukan, sehingga menambah wawasan ilmu pengetahuan dan teknologi serta menimbulkan perubahan tingkah laku menjadi lebih baik.

Menurut Harold Lassewel (Sumantri, 2015: 355) komunikasi dinyatakan dengan 5 unsur, yaitu: (1) Komunikator (source, sender); (2) Pesan (message); (3) Media (chanel); (4) Komunikan (receiver); (5) Efek (effect,influence). Dalam proses pembelajaran guru sebagai komunikator, materi pelajaran sebagai pesan, perangkat pembelajaran sebagai media, siswa sebagai komunikan, dan pengetahuan berupa hasil belajara sebagai efek. Komunikasi yang dimaksud penulis ialah hubungan atau interaksi antara guru dengan siswa yang berlangsung pada saat proses pembelajaran atau dalam istilah lain yaitu hubungan antara guru dengan siswa dalam pelaksanaan proses pembelajaran.

Model pembelajaran integratif adalah salah satu model pembelajaran yang dapat melibatkan siswa secara aktif dan tidak monoton berpusat pada guru, sehingga dapat terjalin interaksi yang baik antara guru dan siswa selama proses belajar mengajar berlangsung. Model ini dirancang untuk membantu siswa mencapai dua tujuan belajar yang saling terkait. Pertama, membangun pemahaman mendalam tentang bangunan pengetahuan sistematis. Kedua, mengembangkan kemampuan berpikir kritis (Eggen \& Kauchak, 2012: 259).

Model pembelajaran integratif menggabungkan keempat fase saling terkait, yaitu fase berujung-terbuka (siswa mendeskripsikan, membandingkan, dan mencari pola), fase kausal (siswa memberikan penjelasan bagi kesamaan dan perbedaan), fase hipotesis, serta fase penutup dan penerapan (siswa melakukan generalisasi untuk membuat hubungan yang luas). Dari keempat fase ini siswa dilatih untuk membangun pemahaman yang mendalam dengan latihan menemukan pola, menyusun penjelasan, membuat hipotesis, dan melakukan generalisasi. Dengan dituntut aktif dalam pembelajaran, akan membuat siswa memberikan perhatian lebih terhadap pembelajaran serta adanya ketertarikan siswa terhadap pembelajaran matematika membuat siswa lebih termotivasi dalam mengikuti pembelajaran matematika.

Penelitian dengan model pembelajaran integratif ini penting dilakukan dan model ini telah diteliti oleh beberapa peniliti sebelumnya. Penelitian yang dilakukan oleh Ulfa (2014) yang memberikan hasil bahwa hasil belajar matematika siswa dengan model pembelajaran Integratif lebih baik dibandingkan dengan model pembelajaran konvensional. Penelitian yang dilakukan oleh Pohan dan Manurung (2015), dari hasil penelitian menunjukkan bahwa hasil belajar siswa dengan model pembelajaran Integratif lebih baik dibandingkan dengan model pembelajaran konvensional pada materi koligatif larutan.

Menurut Arifin (2011: 12-13), kata dasar "pembeljaran" adalah belajar. Dalam arti sempit pembelajaran dapat diartikan sebagai suatu proses atau cara yang dilakukan agar seseorang dapat melakukan kegiatan belajar. Sedangkan dalam arti luas, pembelajaran adalah suatu peoses atau kegiatan yang sistematis dan sistematik, yang bersifat interaktif dan komunikatif antara pendidik (guru) dengan peserta didik, sumber belajara dan lingkungan untuk menciptakan suatu kondisi yang memungkinkan terjadinya tindakan belajar peserta didik, baik di kelas maupun di luar kelas, dihadiri guru secara fisik atau tidak, untuk menguasai kompetensi yang telah ditenetukan.

Kamus besar Bahasa Indonesia, mengartikan kata matematika sebagai "ilmu tentang bilangan-bilangan, hubungan antar 
bilangan, dan prosedur operasional yang digunakan dalam penyelesaian masalah mengenai bilangan". Jadi matematika merupakan ilmu pengetahuan tentang bilanganbilangan yang diperoleh dengan cara bernalar.

Menurut Uno dalam Fitri (2014: 18), pembelajran matematika adalah suatu aktivitas mental untuk memahami arti hubunganhubungan serta symbol-simbol kemudian diterapkan pada situasi nyata. Belajar matematika berkaitan dengan apa dan bagaimana menggunkannya dalam membuat keputusan begitupun dalam menyelesaikan masalah. Peranan guru penting dalam pembelajaran matematika, sebab salah satu faktor yang mempengaruhi kesanggupan siswa pada mata pelajaran matematika adalah cara mengajar guru.

Menurut Suherman dalam Fitri (2014: 18), pembelajaran matematika merupakan proses dimana siswa secara aktif mengkonstruksi pengeetahuan matematika. Pengetahuan matematika akan lebih baik jika siswa mampu mengkonstruksi melalui pengalaman yang telah mereka miliki sebelumnya. Untuk itu, keterlibatan siswa secara aktif sangan penting dalam kegiatan pembelajaran. Dalam hal ini pembelajaran matematika merupakan pembenetukan pola piker dalam penalaran suatu hubungan antara suatu konsep dengan konsep yang lainnya.

Model integratif adalah sebuah model pengajaran atau instruksional untuk membantu siswa mengembangkan pemahaman mendalam tentang bangunan pengetahuan sistematis sambal secara bersamaan melatih keterampilan berpikir kritis siswa.

Model integratif dirancang untuk membantu siswa mencapai dua tujuan belajar yang saling terkait. Pertama, membangun pemahaman mendalam tentang bangunan pengetahuan sistematis. Kedua, mengembangkan kemampuan berpikir kritis. Bangunan pengetahuan sistematis (Organized Bodies of Knowledge), yaitu satu topik yang mengkombinasikan fakta, konsep, generalisasi, dan hubungan antara semuanya (Eggen \& Kauchak, 2010). Mengembangkan kemampuan berpikir kritis menuntut latihan menemukan pola, menyusun penjelasan, membuat hipotesis, melakukan generalisasi. mendokumentasikan temuan-temuan yang terbukti.

Menurut Judy dlam Eggen \& Kauchak (2012: 271) menerapkan pelajaran menggunakan model integratif menggabungkan empat fase saling terkait erat yang menekankan berpikir dan strategi untuk meningkatkan motivasi siswa. Fasefase tersebut sebagai berikut:

a. Fase 1: Fase Berjuan - Terbuka

Fase 1 adalah titik awal bagi analisis siswa. Dalam fase ini siswa mendeskripsikan, membandingkan, dan mencari pola-pola didalam data. Dalam fase ini guru membantu siswa mengakrabkan diri dengan data dan juga mulai proses analisis.

b. Fase 2: Fase Kasual

Fase kasual mulai ketika siswa berusaha menjelaskan kesamaan dan perbedaan yang siswa didentifikasi di fase 1. Yaitu, mereka mencari kemungkinan hubungan-hubungan sebab-akibat didalam informasi.

c. Fase 3: Fase Hipotesis

Fase 3 menandai langkah maju tambahan dalam kemampuan siswa menganalisis informasi. Ini berkembang secara langsung dari fase 2. Pertanyaan-pertanyaan pada fase ini meminta siswa untuk berpikir secara hipotesis.

d. Fase 4: Penutup dan Penerapan

Selama fase 4, penutup dan penerapan, siswa melakukan generalisasi untuk membuat hubungan luas, yang meringkas materi. Kemudian, siswa menerapkan pemahaman mereka pada situasi-situasi baru.

\section{Metode}

Jenis penelitian ini adalah penelitian ekperimen semu, dan dilaksanakan pada semester ganjil tahun ajaran 2018/2019 di SMP Negeri 8 Kendari. Populasi dalam penelitian ini adalah seluruh siswa kelas IX SMP Negeri 8 Kendari yang tersebar pada 8 kelas yaitu kelas $\mathrm{IX}_{1}$ hingga IX $\mathrm{I}_{8}$ yang berjumlah 177 orang siswa.

Penentuan sampel penelitian menggunakan teknik purposive sampling, yaitu dengan mengambil dua kelas berbeda yang mempunyai rata-rata nilai ulangan harian yang rendah yang 
relatif sama. Dua kelas yang dipilih adalah kelas $\mathrm{IX}_{3}$ dan kelas $\mathrm{IX}_{4}$. Kemudian, untuk menentukan kelas eksperimen dan kelas kontrol, dilakukan pemilihan secara random (class random sampling). Hasilnya, kelas $\mathrm{IX}_{3}$ sebagai kelas eksperimen dan kelas $\mathrm{IX}_{4}$ sebagai kelas kontrol.
Variabel bebas dalam penelitian ini adalah pembelajaran matematika menggunakan model pembelajaran integrative, sedangkan variabel terikat dalam penelitian ini adalah kemampuan komunikasi matematis siswa yang diajar dengan model pembelajaran integratif. Desain penelitian tersebut dinyatakan dalam tabel berikut:

Tabel 1

Desain penelitian posttest only control group design

\begin{tabular}{|c|c|c|}
\hline Kelas & Perlakuan & posttest \\
\hline Eksperimen & $\mathrm{X}$ & $\mathrm{Y}_{1}$ \\
\hline Kontrol & - & $\mathrm{Y}_{2}$ \\
\hline
\end{tabular}

(Sugiyono, 2015:114)

Keterangan:

$\mathrm{X}=$ Pembelajaran matematika dengan mengunakan model integratif $\mathrm{Y}_{1}=$ Hasil posttest siswa setelah perlakuan pada kelas eksperimen $\mathrm{Y}_{2}=$ Hasil posttest siswa setelah perlakuan pada kelas kontrol

Instrumen yang digunakan dalam penelitian ini terdiri dari tes kemampuan komunikasi matematis siswa digunakan tes tertulis berbentuk uraian (essay). Tes ini digunakan untuk memperoleh data kuantitatif berupa skor kemampuan komunikasi matematis siswa yang disusun berdasarkan indikator kemampuan komunikasi matematis oleh peneliti dan telah dikonsultasikan serta disetujui oleh dosen pembimbing.

Instrumen yang digunakan dalam penelitian ini terdiri dari tes kemampuan komunikasi matematis siswa digunakan tes tertulis berbentuk uraian (essay). Tes ini digunakan untuk memperoleh data kuantitatif berupa skor kemampuan komunikasi matematis siswa yang disusun berdasarkan indikator kemampuan komunikasi matematis oleh peneliti dan telah dikonsultasikan serta disetujui oleh dosen pembimbing.

Uji validitas dan reliabilitas instrumen penelitian dilakukan menggunakan uji validitas konstruks, bertujuan untuk menentukan berfungsi tidaknya suatu soal mengukur hasil belajar matematika berdasarkan kriteria yang telah ditentukan, dalam hal ini adalah kriteria materi, konstruk, dan bahasa. Untuk menguji validitas konstruks instrumen posttest, telah diminta pendapat/penilaian dari ahli yang terdiri dari dua orang dosen jurusan pendidikan matematika FKIP UHO dan satu orang guru mata pelajaran matematika SMP Negeri 8 Kendari.

Analisis validitas penilaian panelis digunakan untuk mengetahui validitas konstruk instrumen melalui penilaian panelis dengan menggunakan rumus:

$$
V=\frac{\sum n_{i}\left|i-l_{o}\right|}{[N(c-1)]}
$$

(Aiken, 2012:36)

Keterangan:

$V=$ Indeks validitas isi

$i=$ dari $l_{0}+1$ sampai $l_{0}+c-1$

$l_{0}=$ skala terendah

$c=$ skala tertinggi

$n_{i}=$ banyak nilai pada $i$

$N=\sum n_{i}$

Nilai $V$ terletak di antara 0 dan 1 (Valid $\geq 0,60)$

Selanjutnya, untuk menguji reliabilitas

instrumen posttest, hasil tes tersebut dianalisis menggunakan rumus Alfa Cronbach.

$$
r_{i}=\frac{k}{k-1}\left\{1-\frac{\sum S_{i}^{2}}{S_{t}^{2}}\right\}
$$

(Lestari dan Yudhanegara,

$$
\text { 2017: 206) }
$$

Keterangan:

$\mathrm{r}_{\mathrm{i}} \quad=$ Koefisien reliabilitas

$\mathrm{k} \quad=$ Banyak butir

$\mathrm{s}_{\mathrm{i}}^{2}=$ Varians skor butir ke-i

$\mathrm{s}_{\mathrm{t}}^{2}=$ Varians skor total.

Selanjutnya dalam pemberian

interpretasi terhadap koefisien reliabilitas tes 
$\left(r_{i}\right)$ pada umumnya digunakan kriteria reliabilitas berdasarkan Guilford (Lestari dan
Yud hanegara, 2017: 206) disajikan dalam Tabel 3 berikut.

Tabel 2

Klasifikasi Koefisien Reliabilitas

\begin{tabular}{|c|c|c|}
\hline & Besarnya $\mathrm{r}_{\mathrm{xy}}$ & Tingkat Reliabilitas \\
\hline 1. & $r_{11} \leq 0,20$ & Sangat Rendah \\
\hline 2. & $0,20<r_{11} \leq 0,40$ & Rendah \\
\hline 3. & $0,40<r_{11} \leq 0,60$ & Sedang \\
\hline 4. & $0,60<r_{11} \leq 0,80$ & Tinggi \\
\hline 5. & $0,80<r_{11} \leq 1,00$ & Sangat Tinggi \\
\hline
\end{tabular}

Pengumpulan data dalam penelitian ini dilakukan dengan pemberian instrumen berupa tes hasil belajar matematika siswa berbentuk uraian (essay) kepada siswa. Setelah kegiatan pembelajaran dengan menerapkan model pembelajaran integratif dilaksanakan, siswa akan diberikan posttest untuk melihat pengaruh model pembelajaran integratif terhadap hasil belajar matematika siswa. Kemudian tes tersebut akan dikerjakan oleh siswa, selanjutnya hasil pekerjaan siswa dikumpulkan oleh peneliti untuk diperiksa, diberi skor, dan diberi nilai hasil belajar matematika siswa. Skor dan nilai hasil belajar matematika dari hasil pekerjaan siswa inilah yang akan dijadikan data dalam penelitian ini.

Data hasil skor yang diperoleh dari hasil jawaban siswa, akan dipergunakan untuk menghitung nilai akhir dalam skala 1-100 dengan rumus, yaitu:

$$
\begin{array}{r}
N=\frac{\text { Skor perolehan }}{\text { skor maksimal }} \times 100 \\
\mathrm{~N}=\text { Nilai Akhir }
\end{array}
$$

Penelitian ini menggunakan analisis deskriptif dan analisis inferensial. Analisis deskriptif Mendeskripsikan data penelitian apa adanya dan tidak digunakan untuk mengambil kesimpulan statistik. Hasil analisis secara deskriptif dilaporkan dalam bentuk mean, median, standar deviasi, varians, nilai minimum, nilai maksimum, skewness dan kurtosis. Penyajian data desktiptif bertujuan untuk memberikan gambaran singkat tentang hasil penelitian supaya lebih mudah dibaca dan dipahami.

Analisis inferensial dimaksudkan untuk menguji hipotesis, namun terlebih dahulu melalui tahapan uji pra-syarat, yaitu uji normalitas data dan uji homogenitas. Uji normalitas data dimaksudkan untuk mengetahui apakah data yang diperoleh berasal dari populasi yang berdistribusi normal atau tidak. Untuk keperluan ini, maka statistik yang digunakan adalah uji Kolmogrov-Smirnov dengan bantuan SPSS. Secara statistik perumusan hipotesis:

$\mathrm{H}_{0}$ : data berasal dari populasi yang berdistribusi normal

$\mathrm{H}_{1}$ : data berasal dari populasi yang tidak berdistribusi normal.

Dengan kriteria pengambilan keputusan, yaitu:

1. Terima $\mathrm{H}_{0}$ jika nilai Asymp. Sig (2-tailed) > $\alpha=0,05$

2. Tolak $\mathrm{H}_{0}$ jika nilai Asymp. Sig (2-tailed) $\leq \alpha$ $=0,05$.

Uji homogenitas dimaksudkan untuk memperlihatkan bahwa dua atau lebih kelompok data sampel berasal dari populasi yang memiliki varians yang sama.

Perumusan hipotesis:

$H_{0}$ : varians dari dua atau lebih kelompok populasi data adalah sama,

$H_{1}$ : varians dari dua atau lebih kelompok populasi adalah tidak sama.

Kriteria pengambilan keputusan dengan menggunakan SPSS sebagai berikut.

a. Jika $F_{\text {hitung }}<F_{\text {tabel }}$ artinya varians kedua kelompok homogen, maka $\mathrm{H}_{0}$ diterima

b. Jika $F_{\text {hitung }} \geq F_{\text {tabel }}$ artinya varians kedua kelompok tidak homogen, maka $\mathrm{H}_{0}$ ditolak.

Setelah dilakukan pengujian populasi data dengan menggunakan normalitas dan homogenitas, pada taraf signifikan $\alpha=0.05$, selanjutnya melakukan uji hipotesis dengan menggunakan rumus uji-t untuk data normal dan homogen, uji t untuk sampel yang homogen, yaitu: 


$$
t_{\text {hitu ng }}=\frac{\overline{X_{1}}-\overline{X_{2}}}{S_{\text {gab }} \sqrt{\frac{1}{n_{1}}+\frac{1}{n_{2}}}}
$$

Keterangan:

$t_{\text {hit }}=$ angka atau koefisien derajat perbedaan mean kedua kelompok

$\bar{X}_{1}=$ rata-rata hasil belajar kelas eksperimen

$\bar{X}_{2}=$ rata-rata hasil belajar kelas kontrol

$n_{1}=$ jumlah siswa kelas eksperimen

$n_{2}=$ jumlah siswa kelas kontrol

$S_{\text {gab }}=$ varians Gabungan

Kriteria pengambilan keputusan untuk uji $\mathrm{t}$ sebagai berikut.

1. Jika $t_{\text {hitung }} \leq t_{\text {tabel }}$ maka $H_{o}$ diterima dan $\mathrm{H}_{1}$ ditolak.

2. Jika $t_{\text {hitung }}>t_{\text {tabel }}$ maka $\mathrm{H}_{\mathrm{o}}$ ditolak dan $\mathrm{H}_{1}$ diterima.

Pengujian hipotesis :

$\mathrm{H}_{\mathrm{o}}: \mu_{1} \leq \mu_{2}$

$\mathrm{H}_{1}: \mu_{1}>\mu_{1}$

Keterangan:

$\mu_{1}=$ nilai rata-rata hasil belajar matematika siswa yang diajar dengan model pembelajaran integratif. $\mu_{2}=$ nilai rata-rata hasil belajar matematika siswa yang diajar dengan model pembelajaran langsung.

Hipotesis yang diajukan:

$\mathrm{H}_{0}=$ tidak ada pengaruh yang signifikan penggunaan model pembelajaran integratif terhadap hasil belajar matematika siswa kelas VIII SMP Negeri 4 Kendari.

$\mathrm{H}_{1}=$ ada pengaruh yang signifikan penggunaan model pembelajaran integratif terhadap hasil belajar matematika siswa kelas VIII SMP Negeri 4 Kendari

Pada penelitian ini untuk mengukur kemampuan komunikasi matematis siswa digunakan instrumen penelitian berupa tes tertulis dalam bentuk uraian. Tes ini digunakan untuk memperoleh data berupa skor kemampuan komunikasi matematis siswa yang disusun berdasarkan indikator kemampuan komunikasi matematis oleh peneliti dan telah dikonsultasikan serta disetujui pembimbing. Sebelum instrumen penelitian tersebut digunakan, terlebih dahulu dilakukan uji panelis untuk mengetahui validitas dan reliabilitasnya.

Penilaian untuk setiap butir soal tes kemampuan komunikasi matematik digunakan pedoman pemberian skor yang disajikan pada tabel 3 berikut. 
Tabel 3

Pedoman Penskoran Butir Soal Tes Kemampuan Komunikasi Matematis

\begin{tabular}{|c|c|c|}
\hline Aspek Komunikasi & Respon Siswa Terhadap Soal & Skor \\
\hline \multirow{4}{*}{$\begin{array}{l}\text { Menyatakan situasi atau } \\
\text { ide-ide matematika dalam } \\
\text { bantuk gambar, diagram } \\
\text { atau grafik }\end{array}$} & $\begin{array}{l}\text { Tidak ada jawaban, kalaupun ada } \\
\text { menunjukkan tidak memahami } \\
\text { konsep sehingga informasi yang } \\
\text { diberikan tidak berarti apa-apa }\end{array}$ & 0 \\
\hline & $\begin{array}{l}\text { Gambar, diagram atau tabel yang } \\
\text { dibuat hanya sedikit yang benar }\end{array}$ & 1 \\
\hline & $\begin{array}{l}\text { Membuat gambar, diagram atau } \\
\text { tabel namun kurang lengkap dan } \\
\text { benar }\end{array}$ & 2 \\
\hline & $\begin{array}{l}\text { Membuat gambar, diagram atau } \\
\text { tabel dengan lengkap dan benar }\end{array}$ & 3 \\
\hline \multirow{4}{*}{$\begin{array}{l}\text { Menyatakan } \\
\text { gambar, diagram atau benda } \\
\text { nyata ke dalam bahasa, } \\
\text { simbol, ide atau model } \\
\text { matematika }\end{array}$} & $\begin{array}{l}\text { Tidak ada jawaban, kalaupun ada } \\
\text { menunjukkan tidak memahami } \\
\text { konsep sehingga informasi yang } \\
\text { diberikan tidak berarti apa-apa }\end{array}$ & 0 \\
\hline & $\begin{array}{l}\text { Hanya sedikit dari model } \\
\text { matematika yang benar }\end{array}$ & 1 \\
\hline & $\begin{array}{l}\text { Membuat model matematika } \\
\text { dengan benar dan melakukan } \\
\text { perhitungan, namun sedikit } \\
\text { kesalahan dalam mendapatkan } \\
\text { solusi }\end{array}$ & 2 \\
\hline & $\begin{array}{lcr}\text { Membuat } & \text { model } & \text { matematika } \\
\text { dengan benar, } & \text { melakukan } \\
\text { perhitungan dan mendapatkan } & \text { man } \\
\text { solusi secara lengkap dan benar }\end{array}$ & 3 \\
\hline \multirow{5}{*}{$\begin{array}{l}\text { Menjelaskan ide, situasi dan } \\
\text { relasi matematika secara } \\
\text { tulisan dan menyusun } \\
\text { argumen atau } \\
\text { mengungkapkan pendapat } \\
\text { serta memberikan } \\
\text { penjelasan atas jawaban }\end{array}$} & $\begin{array}{l}\text { Tidak ada jawaban, kalaupun ada } \\
\text { menunjukkan tidak memahami } \\
\text { konsep sehingga informasi yang } \\
\text { diberikan tidak berarti apa-apa }\end{array}$ & 0 \\
\hline & $\begin{array}{l}\text { Hanya sedikit penjelasan yang } \\
\text { benar }\end{array}$ & 1 \\
\hline & $\begin{array}{l}\text { Penjelasan secara matematik masuk } \\
\text { akal, namun hanya sebagian } \\
\text { lengkap dan benar }\end{array}$ & 2 \\
\hline & $\begin{array}{l}\text { Penjelasan secara matematik masuk } \\
\text { akal dan benar, meskipun tidak } \\
\text { tersusun secara logis dan masih ada } \\
\text { sedikit kesalahan }\end{array}$ & 3 \\
\hline & $\begin{array}{l}\text { Penjelasan secara matematik masuk } \\
\text { akal, benar dan tersusun secara } \\
\text { logis }\end{array}$ & 4 \\
\hline
\end{tabular}

Pengumpulan data dalam penelitian ini dilakukan dengan pemberian instrumen penelitian berupa lembar observasi dan tes kemampuan komunikasi matematis berbentuk tes uraian. Observasi dilakukan pada setiap pertemuan yaitu sebanyak empat kali pertemuan. Pada saat proses pembelajaran dengan menggunakan model pembelajaran integratif berlangsung di kelas, maka dilakukan observasi. Hasilnya dipergunakan untuk 
memperoleh data tentang aktivitas/partisipasi guru dan siswa. Untuk tes kemampuan komunikasi matematis dilakukan sebanyak satu kali yaitu pada saat posttest. Setelah kegiatan pembelajaran dengan model integratif dilakukan, maka diadakan posttes pada kelas eksperimen dan kontrol untuk mengetahui kemampuan komunikasi matematis siswa yang diperoleh pada kedua kelas. Kemudian soal tersebut dikerjakan oleh siswa, masing-masing soal yang telah dikerjakan diberikan skor disesuaikan berdasarkan pedoman penskoran kemampuan komunikasi matematis. Selanjutnya hasil pekerjaan siswa dikumpulkan oleh peneliti untuk diperiksa dan dikoreksi serta diberi skor. Skor dari hasil pekerjaan siswa tersebut sebelumnya telah dikonversi menjadi nilai yang kemudian dijadikan data dalam penelitian ini.

\section{Hasil}

Data kuantitatif dalam penelitian ini diperoleh hasil tes kemampuan komunikasi matematis siswa. Tes kemampuan komunikasi matematis siswa dilakukan setelah proses pembelajaran dengan menggunakan soal yang telah dinyatakan valid.hasil analisis deskriptif data tes kemampuan komunikasi matematis siswa kelas ekperimen dan kelas kontrol dengan menggunakan aplikasi dapat dilihat pada tabel 3 berikut:

Tabel 3

Data hasil tes pada kelas eksperimen dan kelas kontrol

\begin{tabular}{|c|c|c|c|}
\hline & & Eksperimen & Kontrol \\
\hline \multirow[t]{2}{*}{$\mathrm{N}$} & Valid & 21 & 19 \\
\hline & Missing & 0 & 2 \\
\hline \multicolumn{2}{|c|}{ Mean } & 66,67 & 54,74 \\
\hline \multicolumn{2}{|c|}{ Median } & 65,00 & 60,00 \\
\hline \multicolumn{2}{|c|}{ Mode } & 65 & 70 \\
\hline \multicolumn{2}{|c|}{ Std. Deviation } & 13,814 & 17,117 \\
\hline \multicolumn{2}{|c|}{ Variance } & 190,833 & 292,983 \\
\hline \multicolumn{2}{|c|}{ Skewness } & $-0,352$ & $-0,284$ \\
\hline \multicolumn{2}{|c|}{ Std. error of skewness } & 0,501 & 0,524 \\
\hline \multicolumn{2}{|c|}{ Minimum } & 35 & 30 \\
\hline \multicolumn{2}{|c|}{ Maximum } & 90 & 80 \\
\hline
\end{tabular}

Hasil analisis deskriptif kemampuan komunikasi matematis siswa pada kelas eksperimen yang diajar dengan menggunakan model pembelajaran integrative diperoleh nilai rata-rata (mean) 66,67, nilai tengah (median) adalah 65,00 , nilai yang paling sering muncul (modus) adalah 65, nilai terendah (nilai minimum) adalah 35 , nilai tertinggi (nilai maksimum) adalah 90 dengan standar deviasi 13,814 dan varians 190,833 sedangkan kelas tengah (median) adalah 60,00 , nilai yang paling sering muncul (modus) adalah 70, nilai terendah (nilai minimum) adalah 30 , nilai tertinggi (nilai maksimum) adalah 80 dengan standar deviasi 17,117 dan varians 292,983 .

Adapun distribusi frekuensi kemampuan pemecahan masalah matematis kelas eksperimenan kelas kontrol dapat dilihat pada Tabel 4 berikut. 
Tabel 4

Distribusi Frekuensi dan Klasifikasi Kemampuan Komuikasi Matematis Siswa Kelas Eksperimen

\begin{tabular}{|c|l|l|l|}
\hline $\begin{array}{c}\text { Rentang } \\
\text { Nilai }\end{array}$ & \multicolumn{1}{|c|}{ Kategori } & Frekuensi & Peersentase (\%) \\
\hline $80<X \leq 100$ & Sangat Baik & 3 & 14,285 \\
\hline $60<X \leq 80$ & Baik & 11 & 52,380 \\
\hline $40<X \leq 60$ & Cukup & 6 & 28,571 \\
\hline $20<X \leq 40$ & Kurang & 1 & 4,761 \\
\hline $0<X \leq 20$ & Sangat Kurang & 0 & 0 \\
\hline jumlah & $\mathbf{2 1}$ & $\mathbf{1 0 0}$ \\
\hline
\end{tabular}

Tabel diatas menunjukkan bahwa siswa yang memiliki tingkat penguasaan materi sangat baik ada 3 orang atau $14,28 \%$ siswa yang mempunyai tingkat penguasaan materi baik ada 11 orang atau $52,38 \%$, siswa yang mempunyai tingkat penguasaan materi cukup ada 6 orang atau $28,57 \%$, dan siswa yang mempunyai tingkat pemahaman kurang ada 1 orang atau $4,76 \%$.

Pengambilan keputusan untuk normalitas data adalah sebagai berikut :

$\mathrm{H}_{0}$ : Data berdistribusi normal

$\mathrm{H}_{1}$ : Data tidak berdistribusi normal,

Dengan kriteria pengujian:

$\mathrm{H}_{0}$ diterima, jika nilai Asymp.Sig. $>\alpha(0,05)$

Berdasarkan hasil analisis perhitungan uji normalitas diperoleh untuk kelas eksperimen nilai Asympt. $\operatorname{Sig}(2-$ tailed $)=0,341>0.05=$ $\alpha$ maka $\mathrm{H}_{0}$ diterima. Hal ini berarti bahwa data hasil belajar matematika siswa pada kelas eksperimen berdistribusi normal. Sedangkan untuk kelas kontrol diperoleh nilai Asympt. $\operatorname{Sig}(2-$ tailed $)=0,517>0.05=\alpha$ maka $\mathrm{H}_{0}$ diterima. Hal ini berarti bahwa data hasil belajar matematika siswa pada kelas kontrol berdistribusi normal.

Uji homogenitas varians digunakan untuk mengetahui apakah varians dari kedua kelompok data tes kemampuan pemecahan masalah matematika siswa homogen atau tidak. Berdasarkan hasil uji homogenitas varians data dari kedua kelompok sampel dengan menggunakan uji-F diperoleh nilai $F_{\text {hitung }}=1,08$ $<\mathrm{F}_{\text {tabel }}=1,74$ maka $\mathrm{H}_{0}$ diterima, sehingga dapat disimpulkan bahwa data kedua kelompok memiliki varians yang sama (homogen). Karena data yang diperoleh berdistribusi normal dan homogen, maka selanjutnya dilakukan pengujian hipotesis dengan uji-t. Berdasarkan hasil analisis uji-t diperoleh $\mathrm{t}_{\text {hitung }}=4,742>\mathrm{t}_{\text {tabel }}=$ 1,666 berada didaerah penolakan $\mathrm{H}_{0}$. Karena $\mathrm{H}_{0}$ ditolak, maka dapat disimpulkan bahwa hasil belajar matematika siswa meningkat. Hal ini menunjukkan adanya pengaruh yang signifikan model pembelajaran integratif terhadap hasil belajar matematika siswa kelas IX SMP Negeri 8 Kendari.

\section{Pembahasan}

Jenis penelitian ini adalah penelitian eksperimen tentang pengaruh model pembelajaran integratif terhadap hasil belajar matematika siswa kelas IX SMP Negeri 8 Kendari. Penelitian ini terdapat dua kelas yaitu kelas $\mathrm{IX}_{3}$ sebagai eksperimen dan $\mathrm{IX}_{4}$ sebagai kelas kontrol. Penelitian dilaksanakan pada tanggal 29 Agustus 2019 sampai tanggal 19 September 2019. Waktu pelaksanaan pembelajaran dalam penelitian ini adalah 10 jam pelajaran. Total pertemuan sebanyak 10 pertemuan, yaitu 4 kali pertemuan untuk kelas eksperimen, 4 kali pertemuan untuk kelas kontrol, 1 kali pertemuan untuk post test untuk kelas eksperimen dan 1 kali pertemuan post test untuk kelas kontrol. Post test diberikan waktu selama 80 menit. Sebelum diberikan post test, diberikan perlakuan berupa model pembelajaran integratif pada kelas eksperimen dan model pembelajaran langsung pada kelas kontrol, dengan materi yang sama yaitu materi statistika.

Jenis penelitian ini adalah eksperimen semu. Penelitian ini dilakukan pada tanggal 29 Agustus 2018 sampai dengan 19 September 2018.Pada penelitian ini,digunakan dua kelas, yakni kelas $\mathrm{IX}_{3}$ sebagai kelas eksperimen yang diajar dengan menggunakan model pembelajaran integratif dan kelas $\mathrm{IX}_{4}$ sebagai kelas kontrol yang diajarkan dengan model pembelajaran konvensional. Penelitian ini dilakukan sebanyak 6 kali pertemuan pada 
setiap kelasnya yakni 5 kali pertemuan digunakan untuk kegiatan pembelajaran dan 1 kali pertemuan digunakan untuk pelaksanaan posttest kemampuan komunikasi matematis siswa.

Pertemuan pertama pada kelas eksperimen yang diajar dengan model pembelajaran integratif memiliki beberapa kendala karena pada dasarnya siswa belum terbiasa dengan model pembelajaran yang baru diterapkan. Dimana, model integratif ini melibatkan siswa secara aktif dalam proses pembelajaran sehingga siswa masih membutuhkan waktu lebih untuk menyesuaikan diri dengan model pembelajaran yang diterapkan. Pada pertemuan pertama, saat menyelesaikan LKS beberapa siswa kebingungan untuk menentukan langkah awal untuk menyelesaikan soal. Siswa cenderung hanya menghafalkan rumus tanpa memahami konsep. Tidak semua siswa mampu menyelesikan semua soal latihan pada LKS. Saat pengajar meminta siswa untuk menyelesaikan soal didepan kelas, siswanya antusias dan berpartisipasi aktif dalam menyelesaikan soal.

Pada pertemuan kedua, dengan arahan yang cukup oleh pengajar, situasi dalam kelas lebih tertib dan terkendali dibandingkan pertemuan sebelumnya. Siswa lebih aktif dalam kegiatan pembelajaran salah satunya menjawab soal di depan kelas. Untuk pertemuan ketiga, keempat dan kelima, sama seperti pada pertemuan kedua, proses pembelajaran dalam kelas berjalan dengan baik dan lancar. Siswa juga lebih memahami setiap tahap dalam model pembelajaran integratif yang diterapkan di kelas. Siswa antusias dalam setiap kegiatan pembelajaran yang telah dilakukan dan mulai merasa bertanggung jawab dalam menyelesaikan masalah pada LKS yang diberikan. Seiring dengan hal tersebut, pemahaman siswa terhadap materi juga meningkat. Siswa yang tadinya membutuhkan pengarahan pengajar dalam memberikan kesimpulan juga telah mampu memberikan kesimpulan secara mandiri. Dapat disimpulkan bahwa siswa memerlukan waktu untuk beradaptasi terhadap suatu pembelajaran yang baru diterapkan dalam kelas.

Pada kelas yang diajar dengan model pembelajaran konvensional, tampak keaktifan dan antusias siswa yang sangat berbeda dibandingkan dengan kelas yang diajar dengan menggunakan model pembelajaran integratif. Aktivitas siswa pada kelas yang diajar dengan menggunakan model pembelajaran konvensional sangat beragam. Ketika kegiatan pembelajaran berlangsung, sebagian siswa tampak tidak fokus dalam mengikuti pembelajaran. Perhatian siswa terbagi kedalam hal lain, ada siswa yang berdiskusi dengan teman sebangkunya, ada siswa yang minta izin untuk keluar masuk kelas, ada juga siswa yang mengantuk. Selain itu, pada saat guru bertanya tentang materi yang telah diajarkan apakah siswa telah mengerti atau belum, walaupun siswa belum mengerti tentang materi yang telah diajarkan tersebut, siswa hanya mencatat tulisan di papan tanpa adanya umpan balik dari siswa. Begitupun ketika guru memberikan soal latihan kepada siswa, hanya sebagian kecil siswa yang selalu aktif menyelesaikan soal latihan di depan. Baik di pertemuan pertama, kedua, sampai pertemuan kelimapun, siswa yang aktif menyelesaikan soal hanya siswa yang sama.

Berdasarkan hasil analisis deskriptifdata hasil tes kemampuan komunikasi matematis siswa kelas eksperimen yang diajar dengan model pembelajaran integratif pada materi statistika diperoleh nialai rata-rata (mean) adalah 66,67., nilai tengah (median) adalah 65,00, nilai yang paling sering muncul (modus) adalah 65, yang tersebar dari nilai 35 (nilai minimum) sampai 90 (nilai maksimum) dengan standar deviasi 13,814 dan varians 190,833. Selanjutnya, dari 21 orang siswa yang diselidiki ditemukan 3 orang siswa $(14,285 \%)$ dengan tingkat penguasaan sangat baik, 11 orang siswa $(52,380 \%)$ dengan tingkat penguasaan baik, 6 orang siswa $(28,571 \%)$ dengan tingkat pengusaan cukup, dan 1 orang siswa $(4,761)$ dengan tingkat penguasaan kurang. Ini berarti kemampuan komunikasi matematis siswa yang diajar dengan model pembelajaran integeratif berada dalam kategori baik.

Sedangkan hasil analisis deskriptif kemampuan komunikasi matematis siswa pada kelas kontrol yang diajar dengan model pembelajaran konvensional diperoleh nilai ratarata (mean) adalah 54,74., nilai tengah (median) adalah 60,00 ., nilai yang paling sering muncul (modus) adalah 70, yang tersebar dari nilai 30 (nilai minimum) sampai 80 (nilai maksimum) dengan standar deviasi 17,117 dan varians 292,983. Selanjutnya dari 19 orang siswa yang 
diselidiki ditemukan 9 orang siswa $(47,368 \%)$ dengan tingkat penguasaan baik, 4 orang siswa $(21,052 \%)$ dengan tingkat penguasaan cukup, dan 6 orang siswa $(31,576 \%)$ dengan tingkat pengusaan kurang. Ini berarti kemampuan komunikasi matematis siswa yang diajar dengan model pembelajaran konvensional berada dalam kategori baik.

Dari nilai rata-rata kemampuan komunikasi matematis siswa yang diajar dengan model pembelajaran integratif pada materi statistika lebih baik bila dibandingkan dengan kemampuan komunikasi matematis siswa yang diajar dengan model pembelajara konvensional.

Hipotesis dalam penelitian ini berbunyi "penerapan model pembelajaran integratif efektif terhadap kemampuan komunikasi matematis siswa di kelas IX SMP Negeri 8 Kendari". Berdasarkan uji normalitas data dengan menggunakan uji Kolmogorov-Smirnov denganbantuanSPSSdiperoleh data kemampuan komunikasi matematis untuk kelas eksperimendan kelas kontrol berdistribusi normal. Selanjutnya bardasarkan hasil uji homogenitas varians data kemampuan komunikasi matematis siswa kelas eksperimen dan kelas kontrol menggunakan statistika uji $\mathrm{F}$ mempunyai varians data yang homogen.

Terjadinya perbedaan kemampuan komunikasi matematis ini disebabkan adanya penerapan model pembelajaran integratif pada kelas eksperimen. Model pembelajaran ini melatih siswa untuk dapat berkomunikasi, berdiskusi dan terlibat secara aktif dengan teman sekelasnya, serta melatih siswa untuk lebih menghargai pendapat temannya. Hal ini tentunya dapat berdampak positif terhadap kemampuan komunikasi matematis siswa. Sebab dalam model pembelajaran integratif, siswa dituntut agar lebih aktif. Selain itu, siswa yang pemahamannya tergolong lemah mendapatkan bantuan dari teman yang mempunyai pemahaman lebih tinggi untuk memecahkan suatu masalah yang dihadapinya. Melalui teman, siswa akan merasa lebih nyaman, tidak ada rasa malu-malu, sehingga siswa yang pemahamannya tergolong lemah tidak segan-segan untuk menanyakan kesulitan yang dihadapinya. Keberhasilan yang dicapai juga tercipta karena adanya komunikasi yang baik antar masingmasing siswa. Disamping itu juga, guru dapat memberikan bantuan secara individual, kepada siswa yang membutuhkannya, sedangkan pada pembelajaran konvensional yang berperan aktif dalam proses pembelajaran adalah guru, siswa hanya mendengarkan dan menerima materi yang diberikan oleh guru, tanpa adanya umpan balik dan pengembangan materi dari siswa.

\section{Simpulan dan Saran}

\section{Simpulan}

Berdasarkan pembahasan terhadap hasil penelitian ini, maka diperoleh kesimpulan sebagai berikut:

1. Hasil tes kemampuan komunikasi matematis siswa kelas $\mathrm{IX}_{3}$ SMP Negeri 8 Kendari yang diajar dengan model pembelajaran integratif diperoleh nilai rata - rata (mean) 66,67, nilai tengah (median) adalah 65,00 sehingga dikategorikan sedang, nilai yang paling sering muncul (modus) adalah 65, yang tersebar dari nilai 35 (nilai minimum) sampai 90 (nilai maksimum) dengan standar deviasi 13,814 dan varians 190,833.

2. Hasil tes kemampuan komunikasi matematis siswa kelas $\mathrm{IX}_{4}$ SMP Negeri 8 Kendari yang diajar dengan model pembelajaran konvensional diperoleh nilai rata-rata (mean) 54,74, nilai tengah (median) adalah 60,00 sehingga dikategorikan cukup, nilai yang paling sering muncul (modus) adalah 70, yang tersebar dari nilai 30 (nilai minimum) sampai 80 (nilai maksimum) dengan standar deviasi 17,117 dan varians 292,983.

3. Penerapan model pembelajaran integratif lebih berpengaruh dibandingkan dengan penerapan model pembelajara konvensional terhadap kemampuan komunikasi matematis siswa untuk materi statistika pada siswa kelas IX SMP Negeri 8 Kendari. Karena menghasilkan rata-rata lebih tinggi dibanding konvensional.

\section{Saran}

Berdasarkan kesimpulan diatas, maka peneliti menyarankan hal-hal sebagai berikut:

1. Kepada guru mata pelajaran matematika di SMP Negeri 8 Kendari agar dalam proses pembelajaran, khususnya pada materi satistika untuk menerapkan model pembelajaran integratif.

2. Diharapkan kepada peneliti selanjutnya agar mencoba model pembelajaran integratif pada pokok bahasan lain. 


\section{Daftar Pustaka}

Arifin, Zainal. (2013). Evaluasi Pembelajaran(Edisi Revisi), Direktorat Jendral Pendidikan Islam Kementrian Agama Jakarta, dilihat tanggal 1 Februari 2017, http://winarno.staff.iainsalatiga.ac.id/w p-content/uploads/sites/25/2013/01/34Evaluasi-Pembelajaran.pdf.

Bernard, Martin. (2015). Meningkatkan Kemampuan Komunikasi dan Penalaran serta Disposisi Matematik Siswa SMK dengan Pendekatan Kontekstual Melalui Game Adebe Flash Cs. 4.0. Jurnal Ilmiah Program Studi Pendidikan Matematika. STKIP Siliwangi Bandung. Vol. 4, No. 2, September 2015.

Daryanto. (2013). Inovasi Pembelajaran Efektif. Bandung: CV Yrama Widya.

Eggen, P \& Kauchak, D. (2012). Strategi dan Model Pembelajaran (Mengajarkan Konten dan Keterampilan Berpikir) edisi keenam, edisi terjemahan. Jakarta: PT. Indeks.

Fitri, R. (2014). Penerapan Strategi The Firing Line Pada Pembelajaran Matematika Siswa Kelas XI IPS SMA Negeri 1 Batipuh. Jurnal Pendidikan Matematika. Part 2 Vol.3 (1). Hal. 1822.

Lestari, K.E., Yudhanegara, M.R. (2017). Penelitian Pendidikan Matematika. Bandung: PT Refika Aditama.

Sugiyono, (2015). Statistika untuk Penelitian. Bandung: Alfabeta.

Suherman, H E. (1992). Strategi Belajar Mngajar Matematika. Jakarta: Universitas Terbuka.

Sumantri, M S. (2015). Strategi Pembelajaran Teori dan Praktik di Tingkat Pendidikan Dasar. Jakarta: Rajawali Pers.
Ulfa, Mardhiya. (2014). Penerapan Model Integratif pada Pembelaaran Matematika Siswa Kelas VIII SMP Negeri 2 Padang,. Dilihat 16 Januari 2018,

$<$ http://ejurnal.bunghatta.ac.idindex.php ?journal=JFKIP\&page $=$ article $\&$ op $=$ vie w\&path\%5B5D=3627>.

Wahyudin, D. (2011). Pengantar Pendidikan. Jakarta: Universitas Terbuka. 
BIODATA PENULIS

Randita Cahyani Hamlin lahir di Raha, 23 Mei 1997 merupakan anak kedua dari pasangan suami istri bapak Hamlin Inggu dan ibu Israwati Oempu. Menempuh pendidikan sekolah dasar di SD Negeri 5 Katobu pada tahun 2002 hingga 2008, pendidikan sekolah menengah pertama di SMP Negeri 1 Raha dari tahun 2008 hingga 2011, pendidikan sekolah menengah atas di SMA Negeri 1 Raha pada tahun 2011 hingga 2014. Dan saat ini sedang menempuh pendidikan di Perguruan Tinggi Negeri Universitas Halu Oleo Kendari jurusan Pendidikan Matematika sejak tahun 2014. 